\title{
COMPARATIVE STUDY ON NORMAL AND SKEW BRIDGE OF PSC BOX GIRDER
}

\author{
Pranathi Reddy ${ }^{1}$, Karuna $S^{2}$ \\ ${ }^{1}$ Post Graduate Student, Department of Civil Engineering, The Oxford College of Engineering, Bangalore \\ ${ }^{2}$ Assistant Professor, Department of Civil Engineering, The Oxford College of Engineering, Bangalore
}

\begin{abstract}
Nowadays the demand for high skew bridges has increased, and many bridge decks are built with some form of skew. The behavior of bridge is effected considerably with the presence of skew angle in bridge decks. In the present study an attempt has been made to study the skew bridge comparing with the normal bridge for skew angle 10, 20, 30, 40, 50. The finite element analysis is carried out for single span, two span and three span deck for dead load and moving load (IRC class 70R) loading using software SAP2000 ver.14. The results are presented in terms of displacement, bending moment and shear force.
\end{abstract}

Keywords: Skew bridges, skew angle, PSC box girder, span length

\section{INTRODUCTION}

\section{Box Girder}

Bridge is a structure built to cross obstacles like canal, road, rail or rock valley. Design of bridge is important and complex approach of civil engineer with rapid growth in field of bridge engineering, the conventional bridge has been replaced by most efficient and economical ones. The most common and basic type of bridge, that is widely used for roadways is Girder Bridge. The two most common types of girders that are used in practice are beam and Box Girders. Though box girder design is more complicated, it has wide acceptance due to their structural efficiency, aesthetic appearance, better stability and serviceability. Over years simple RCC box girders used for short spans resulted in long span prestressed concrete bridges. The use of prestressing enables concrete bridge beams to span long distances. Box girders are constructed in single cell, double cell or multicell.

\section{Skew Bridge}

A Bridge built obliquely between abutments is called as Skew Bridge. The angle between the normal to the center line of the bridge and the center line of the abutment is known as Skew Angle. Skew bridges are built where geometry cannot accommodate straight bridge. Highway should be straight as long as possible in provision of high speed and safety requirements of the traffic, this resulted in increase in number of skew bridges.

Generally bridge with a skew angle less than $20^{\circ}$ is designed as normal bridge. If it is more than $20^{\circ}$ there is change in the behavior of the skew bridge. Thus Geometry and behavior of skew bridge are affected by the presence of skew angle. The Structural response of skewed bridge to stresses in slab and reactions on abutments can be significantly altered by the skew angle of the substructure.

\section{Characteristics of Skew Deck}

- The load tends to take a shortest path to nearest support i.e., obtuse corners of the bridge.

- Increase in reactions and shear forces near obtuse corner.

- Decrease in reactions and possibly uplift in acute corner.

- With increase in skew angle, the stresses, deflections and moment in the bridge deck and reactions on the abutment differs significantly which is studied in this paper.

\subsection{Objective}

The objective of present study is to compare normal and skew bridge of box girder type, with parameter such as displacements, bending moments and shear forces for single, two and three spans deck slab by considering IRC class 70R loading.

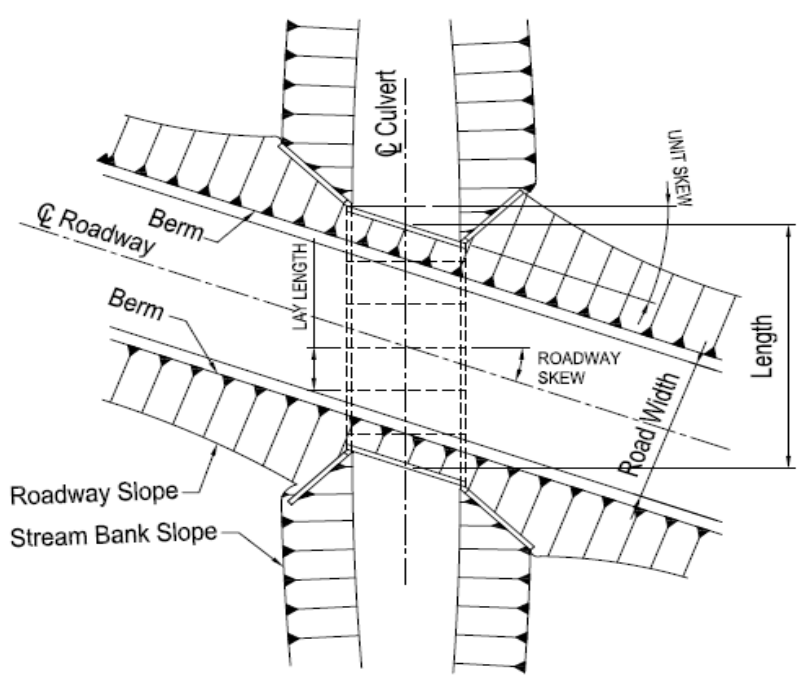

Fig.1 Schematic diagram of skew bridge 


\section{MODELLING AND ANALYSIS}

A simply supported, single span, two span and three span, two lane PSC slab bridge deck is considered in the present study. The different bridge spans considered are $30 \mathrm{~m} 60 \mathrm{~m}$ and $90 \mathrm{~m}$ and skew angle is varied from $0^{\circ}$ to $50^{\circ}$ at $10^{\circ}$ interval, with the depth of the slab $750 \mathrm{~mm}$ for all spans. Beam depth of $1.5 \mathrm{~m}$ and width of $0.3 \mathrm{~m}$ is provided. The bridge deck is analyzed for Dead load, Live load i.e., IRC class 70R considered from table 2 of IRC 6:2000 and Temperature load effect. Comparison of critical structural response of above class is analysed for the models listed in the table (2). A total of 18 slab deck models generated and analyzed using SAP2000 ver. 14.

Table-1 Material Properties

\begin{tabular}{|l|l|l|l|}
\hline $\begin{array}{l}\text { Grade of } \\
\text { Concrete }\end{array}$ & $\begin{array}{l}\text { Elastic } \\
\text { Modulus }\end{array}$ & $\begin{array}{l}\text { Poisson's } \\
\text { Ratio }\end{array}$ & $\begin{array}{l}\text { Density } \\
\text { of } \\
\text { concrete }\end{array}$ \\
\hline $\mathrm{M}-40$ & $35 \mathrm{Mpa}$ & 0.15 & $25 \mathrm{kN} / \mathrm{m}^{3}$ \\
\hline
\end{tabular}
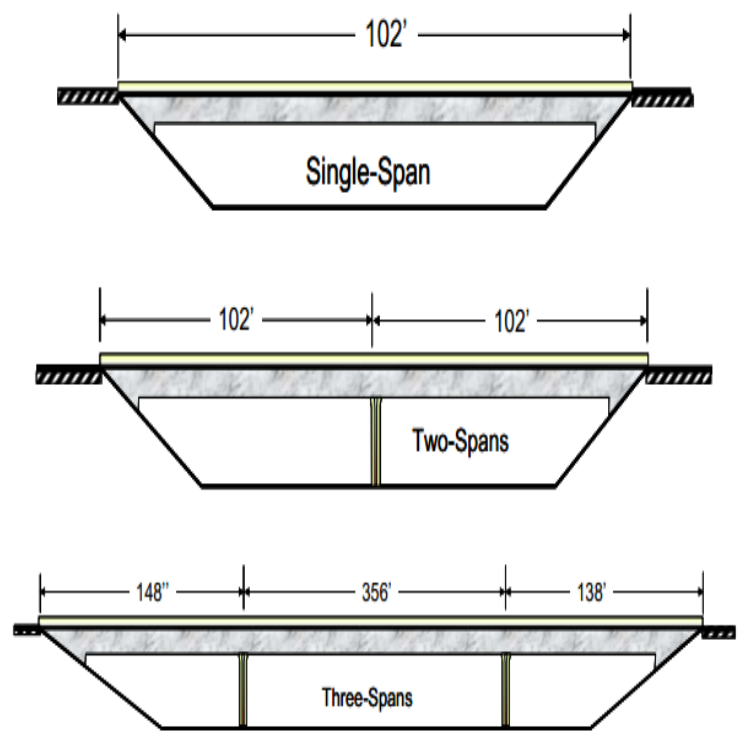

Fig.2 Bridge of different spans 30, 60, 90m

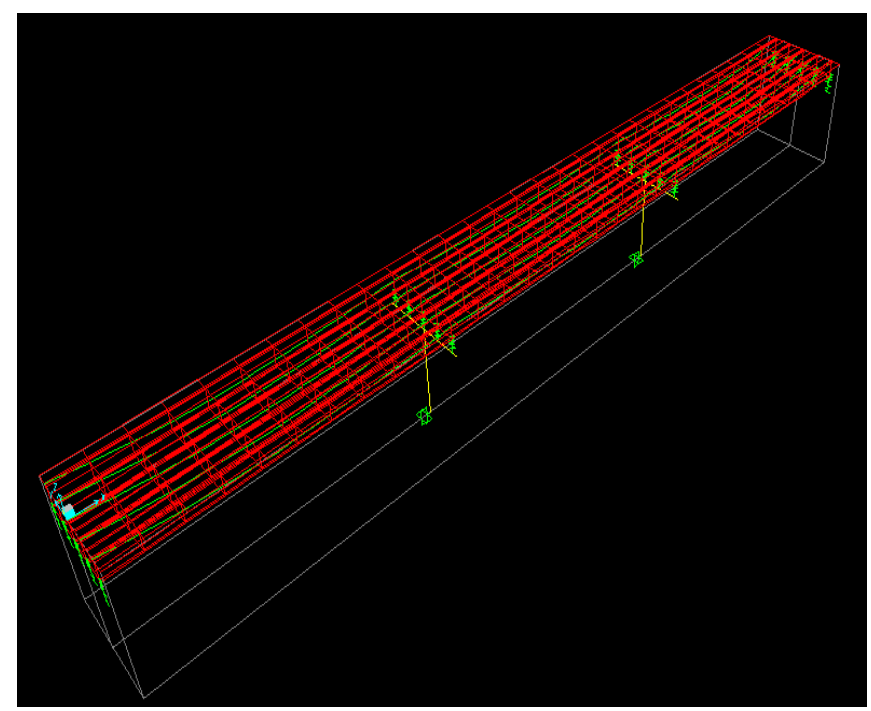

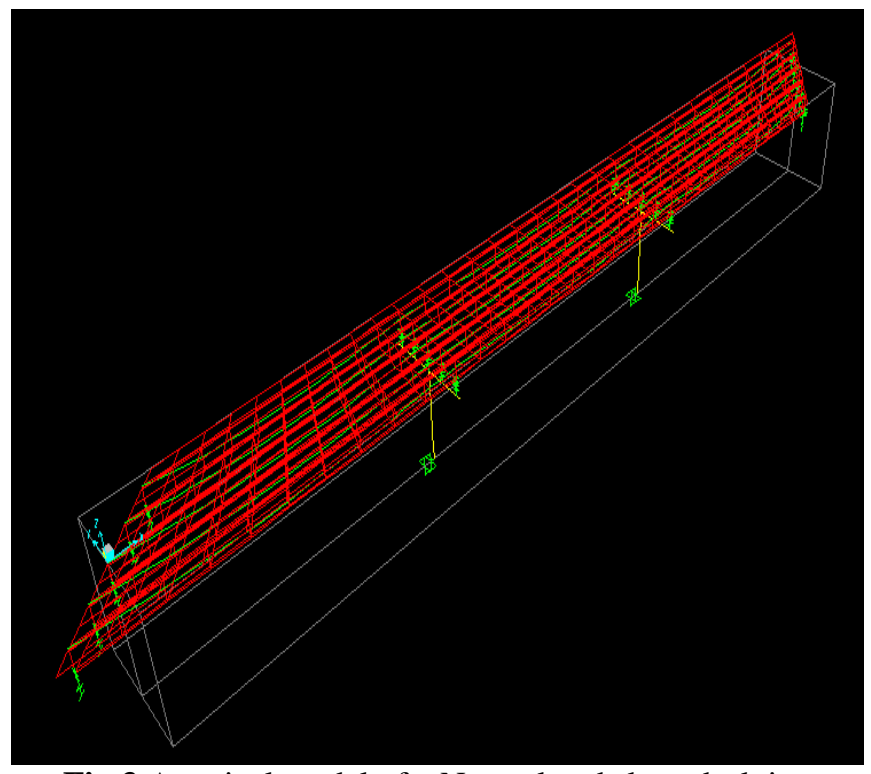

Fig.3 A typical model of a Normal and skew deck in SAP2000

Table-2 Bridge Deck Models

\begin{tabular}{|l|l|l|l|l|l|}
\hline No. & $\begin{array}{l}\text { Span } \\
(\mathrm{m})\end{array}$ & $\begin{array}{l}\text { Skew } \\
\text { Angle }\end{array}$ & $\begin{array}{l}\text { No. } \\
(\mathrm{m})\end{array}$ & $\begin{array}{l}\text { Skew } \\
\text { Angle }\end{array}$ \\
\hline 1. & 90 & $0^{\circ}$ & 10. & 60 & $30^{\circ}$ \\
\hline 2. & 90 & $10^{\circ}$ & 11. & 60 & $40^{\circ}$ \\
\hline 3. & 90 & $20^{\circ}$ & 12. & 60 & $50^{\circ}$ \\
\hline 4. & 90 & $30^{\circ}$ & 13. & 30 & $0^{\circ}$ \\
\hline 5. & 90 & $40^{\circ}$ & 14. & 30 & $10^{\circ}$ \\
\hline 6. & 90 & $50^{\circ}$ & 15. & 30 & $20^{\circ}$ \\
\hline 7. & 60 & $0^{\circ}$ & 16. & 30 & $30^{\circ}$ \\
\hline 8. & 60 & $10^{\circ}$ & 17. & 30 & $40^{\circ}$ \\
\hline 9. & 60 & $20^{\circ}$ & 18. & 30 & $50^{\circ}$ \\
\hline
\end{tabular}

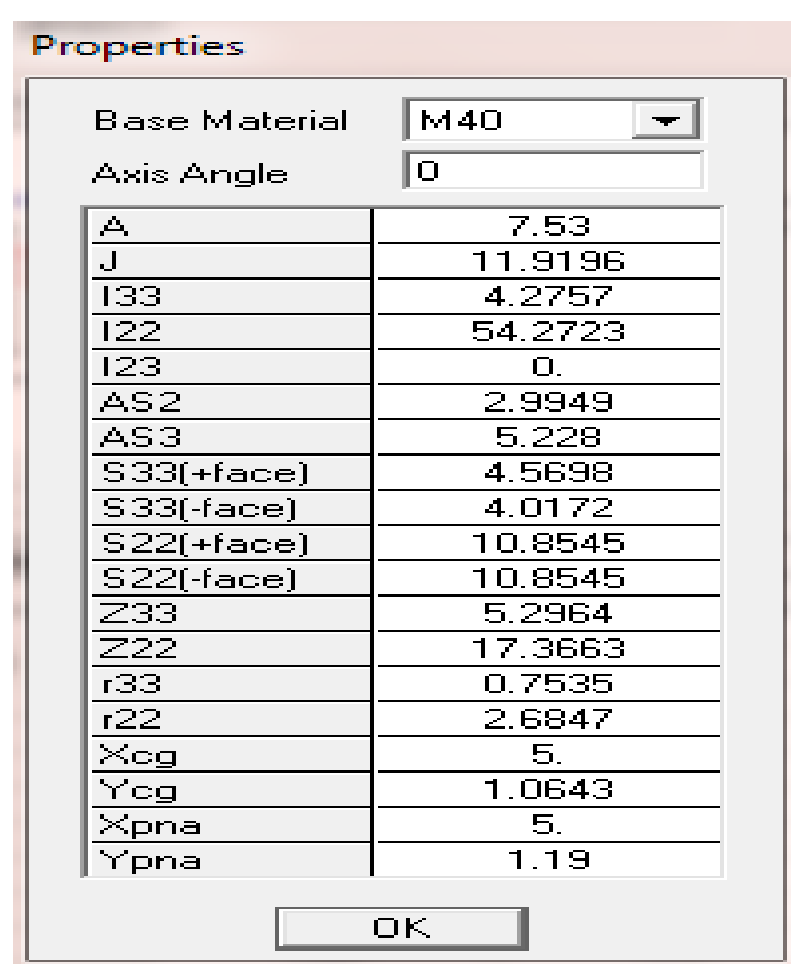



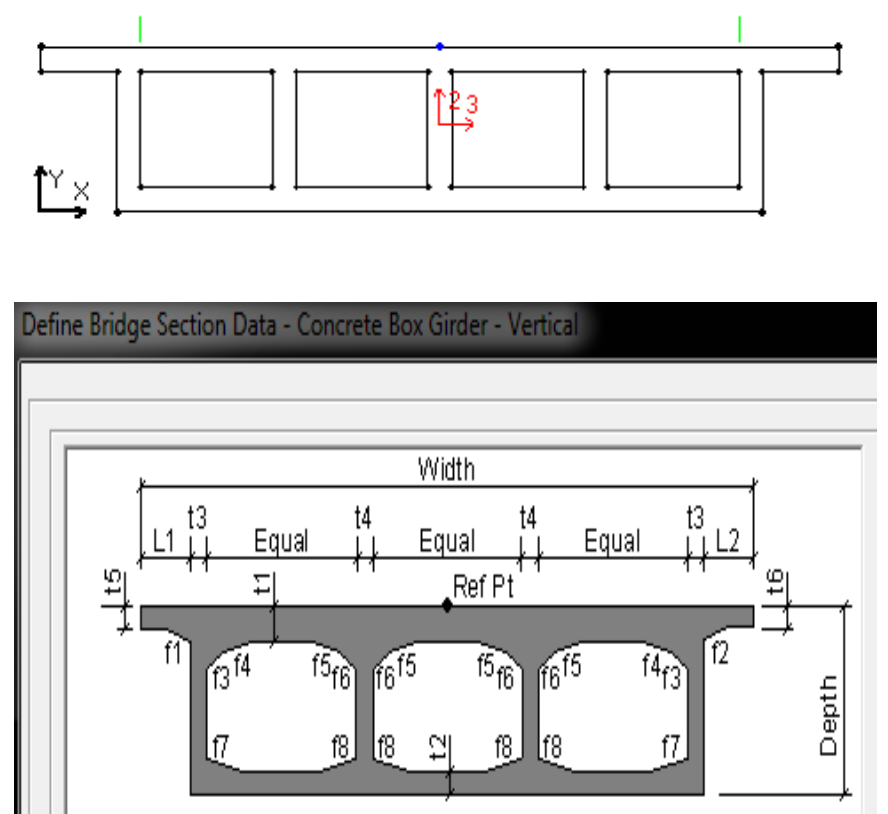

Section Data

\begin{tabular}{|l|c|}
\hline \multicolumn{1}{|c|}{ Item } & Value \\
\hline P8Vertical Dimension & 0. \\
\hline Left Overhang Data & \\
\hline Left Overhang Length (L1) & 0.95 \\
\hline Left Overhang Outer Thickness (15) & 0.3 \\
\hline Right Overhang Data & \\
\hline Right Overhang Length (L2) & 0.95 \\
\hline Right Overhang Outer Thickness (66) & 0.3 \\
\hline Live Load Curb Locations & 1.25 \\
\hline Distance To Inside Edge of Left Live Load Curb & 1.25 \\
\hline Distance To Inside Edge of Right Live Load Curb & 0. \\
\hline Distance To Centerline of Median Live Load Curb & 0. \\
\hline Width of Median Live Load Curb & \\
\hline Insertion Point Location & 0. \\
\hline OffsetX Xrom Reference Point To Insertion Point & 0. \\
\hline Offset Y From Reference Point To Insertion Point & \\
\hline Design Data & 0.6096 \\
\hline Top Slab Cut Line Distance (From Top of Section) \\
\hline Bottom Slab Cut Line Distance (From Bottom of Section) & 0.3556 \\
\hline \hline
\end{tabular}

Fig.4 Details of Deck slab and Box Girder

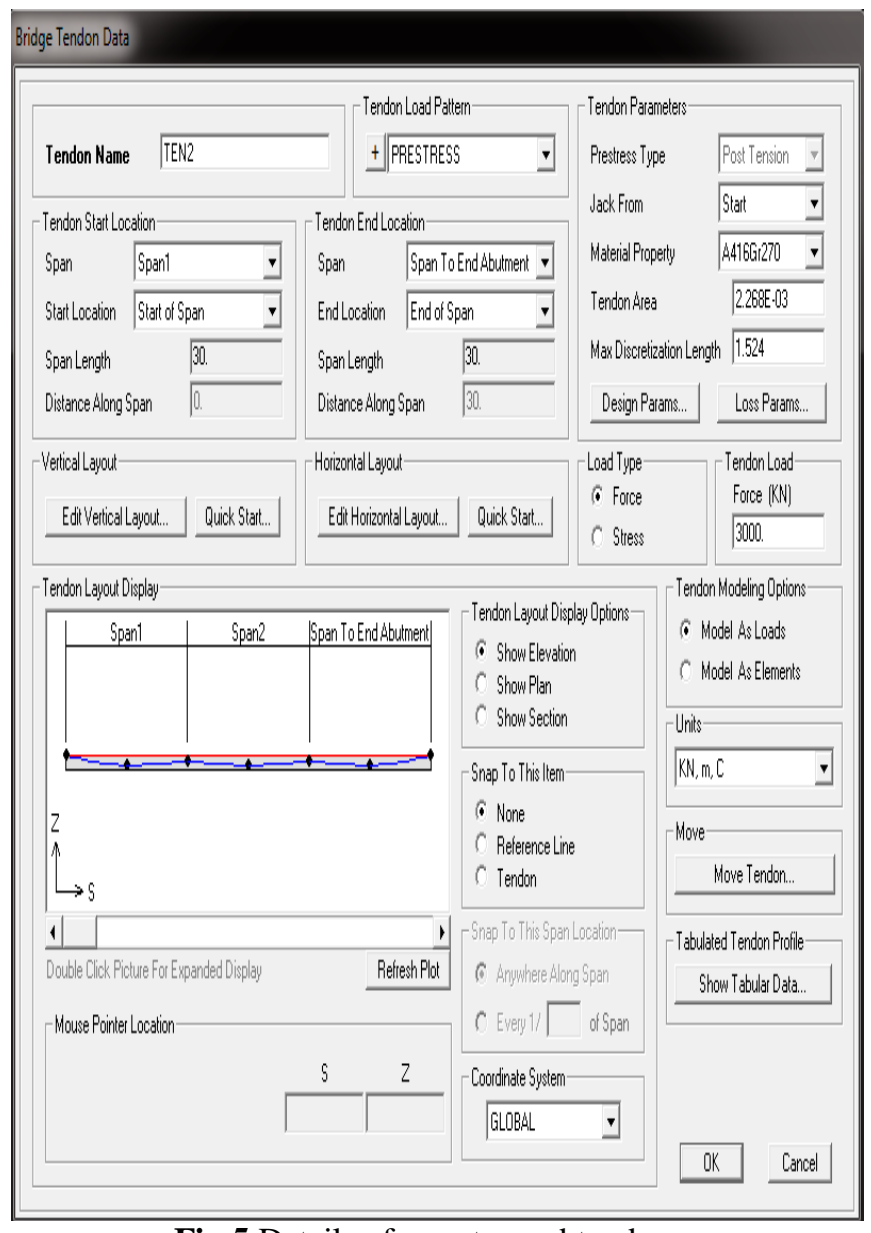

Fig.5 Details of pre-stressed tendons

\section{RESULTS AND DISCUSSIONS}

Detail design and analysis of bridge superstructure for the effect of different skew angles along varying spans has been performed and the results obtained are presented in terms of deflection, bending moment and shear force.

\section{Deflection}

- It is observed that in case of three and two spans for skewed deck slab, max deflection for all types of load i.e., dead load and moving load compared to that of normal deck slab decreases with increase in skew angle as shown in fig. 5(a) and (b).

- Whereas for single span, deflection increase with increase in skew angle for both load cases as shown in fig. 5(c)

- It is also observed that magnitude of deflection is more under Dead load compared to Moving load for two and three spans.

- In case of single span deck slab magnitude of deflection is more under Moving load when compared to Dead load. 


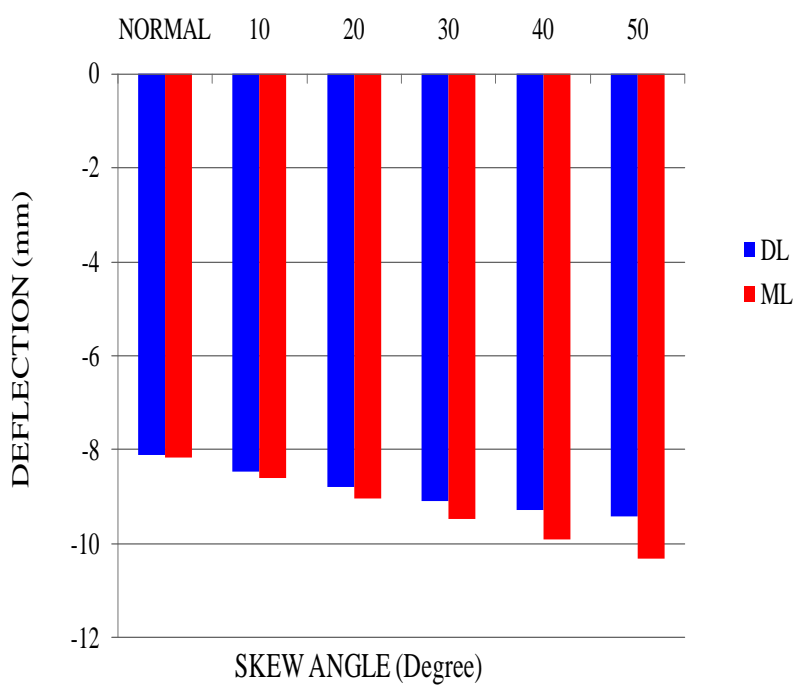

(a) For three span

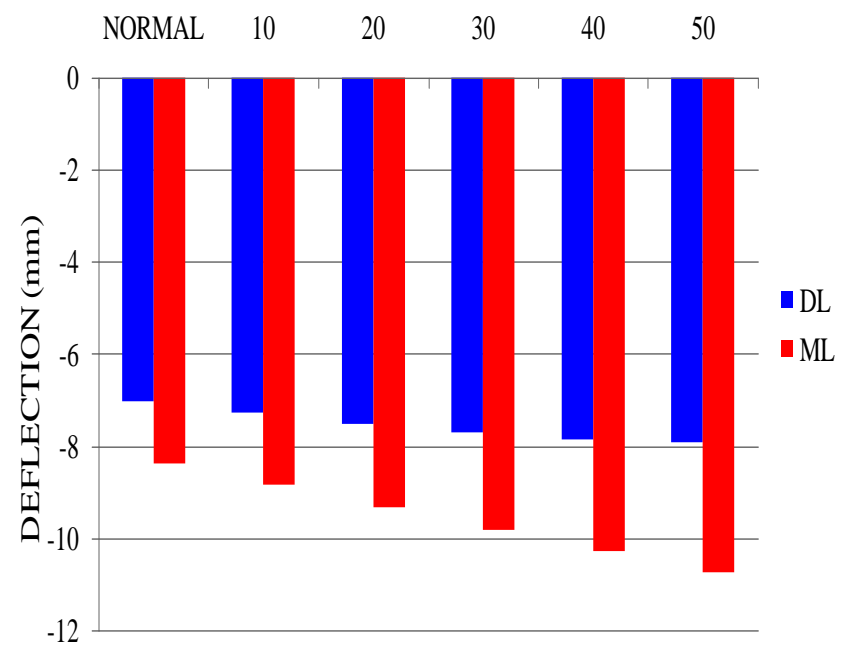

SKEW ANGLE(Degree)

(b) For two span

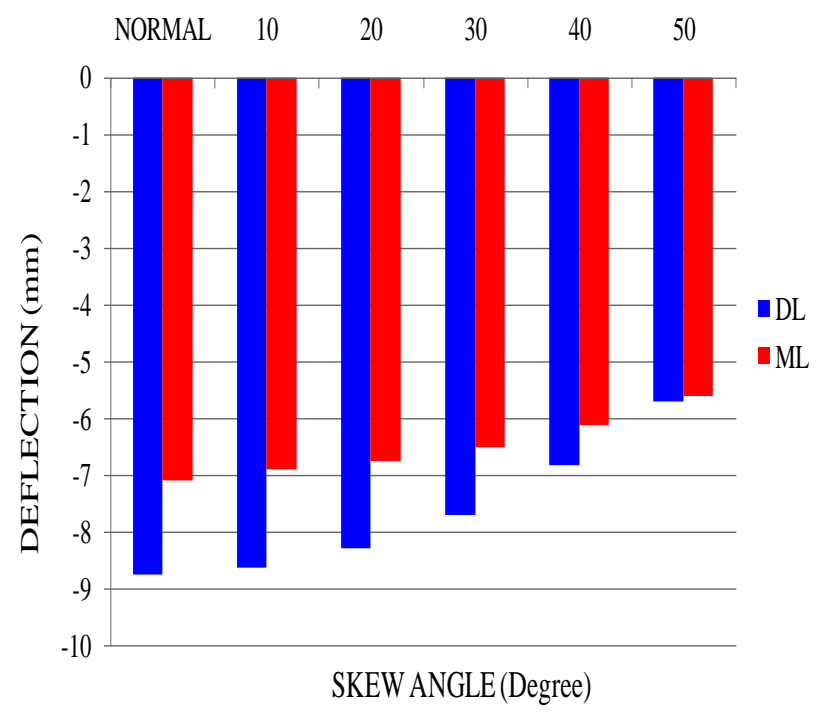

(c) For one span

Fig.5 Variation of deflection for different skew angles

\section{Bending Moment}

- The variation in bending moment along the entire span is presented for dead load, moving load. The results are compared with normal and skew bridges for all the three spans.

- In case of three and two span there is reduction in bending moment with increase in skew angle under dead load, whereas bending moment has increased with increase in skew angle under Moving load as shown in fig. 6(a) and (b)

- In case of single span deck, it is observed that bending moment has decreased with increase in skew angle under dead load, whereas under moving load there is slight reduction in bending moment up to $20^{\circ}$ skew and then increased by $10 \%$ for $30^{\circ}$ and further reduced for $40^{\circ}$ skew angle.

- $\quad$ Bending moment has reached a maximum value for $50^{\circ}$ skew deck slab when compared with all other deck spans as in fig. 6 (c).

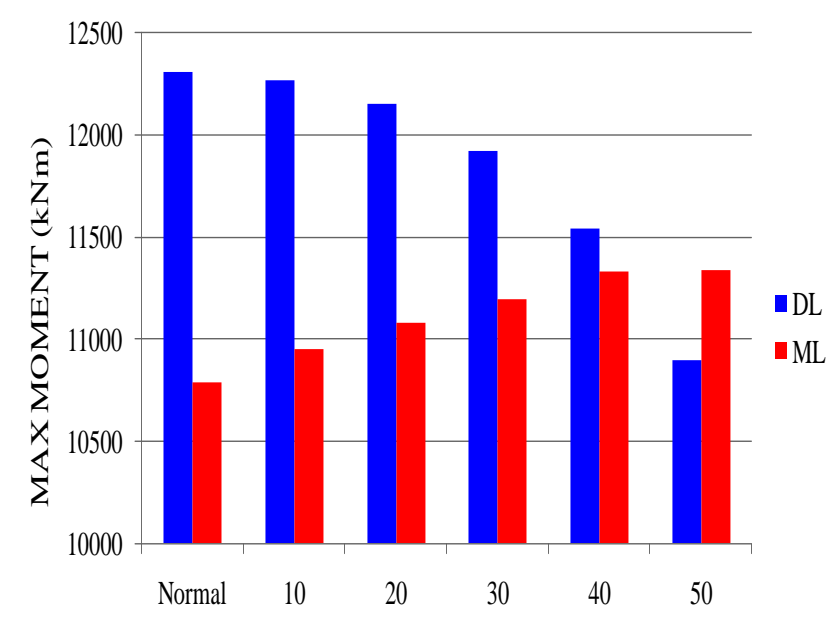

SKEW ANGLE(Degree)

(a) For three span

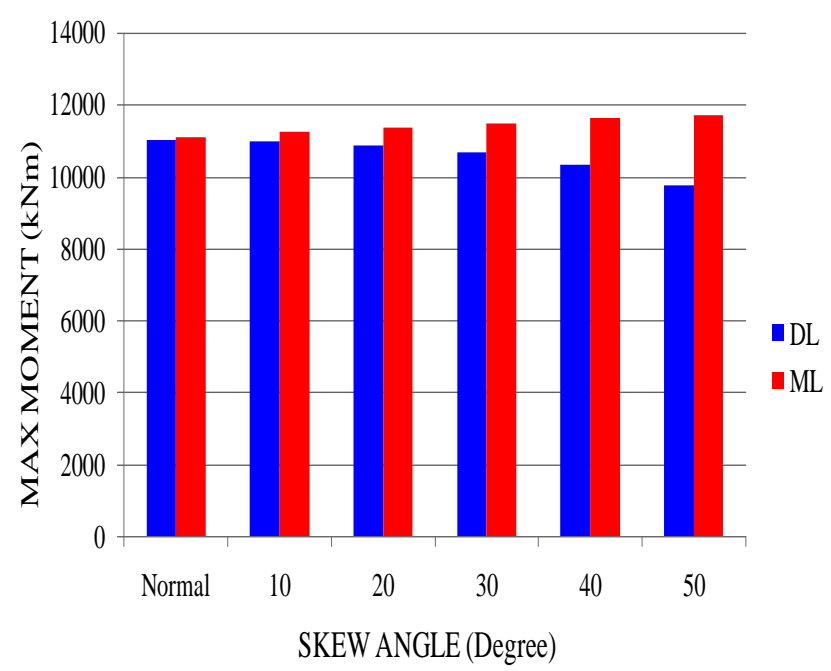

(b) For two span 


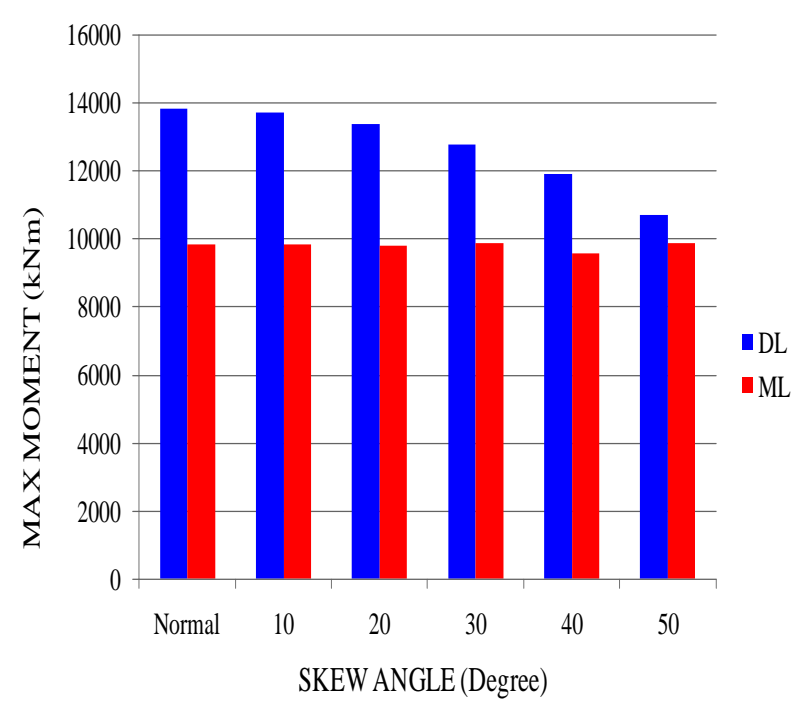

(c) For single span

Fig.6 Variation of bending moment for different skew angle

\section{Shear Force}

In case of three and two span there is reduction in shear force with increase in skew angle under Dead load, whereas shear force has increased with increase in skew angle under Moving load as shown if fig. 7(a) and (b).

- In case of single span, it is observed that the magnitude of shear force remained same with increase in skew angle under Dead load but there is an increase in magnitude under moving loads as shown in fig. 7(c).

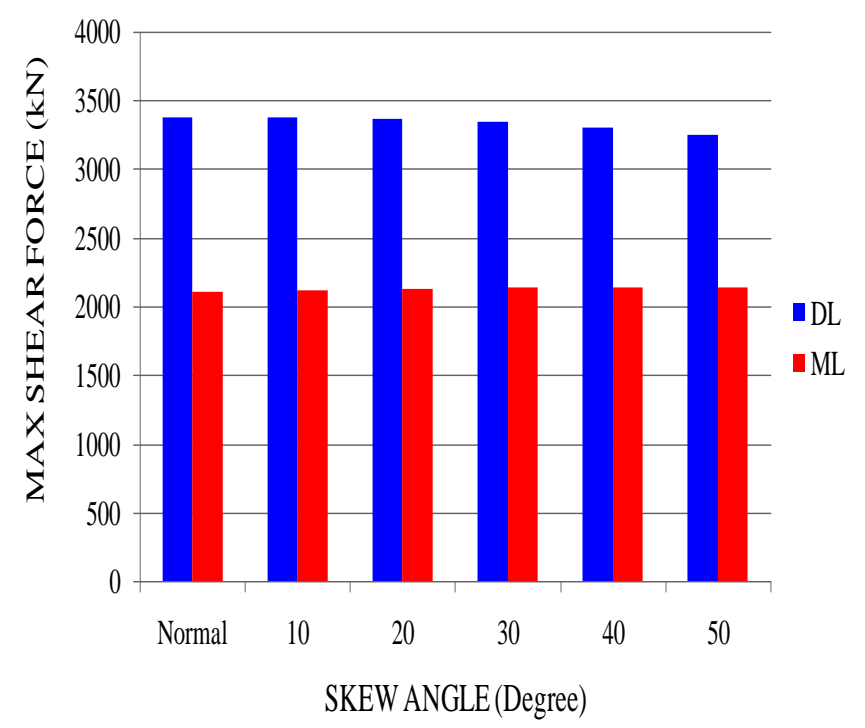

(a) For three span



(b) For two span

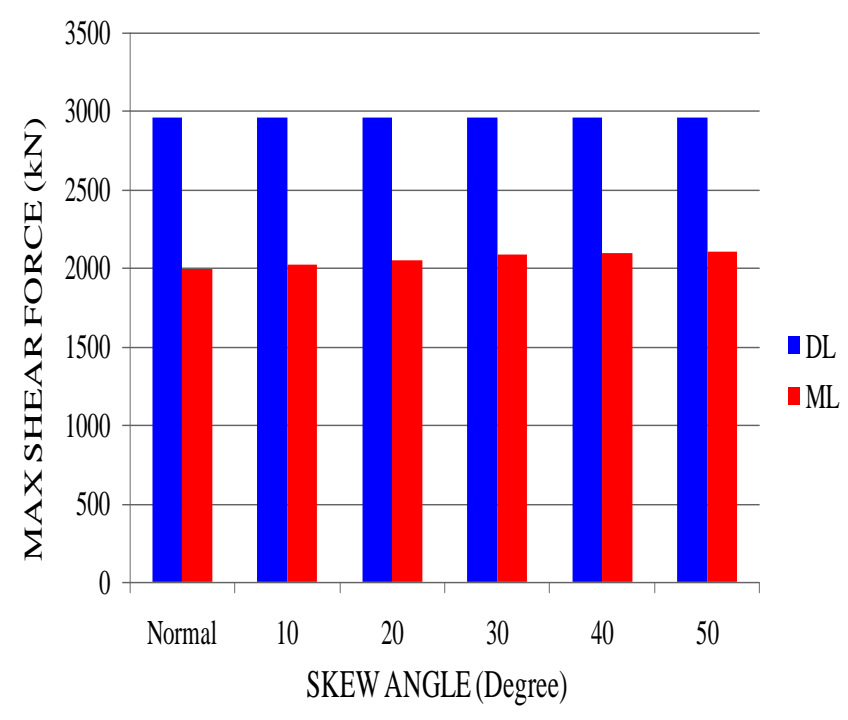

(c) For single span

Fig.7 Variation of shear force along the spans with different skew angles

\section{CONCLUSION}

1. Deflection decreases with increase in skew angle in two or three span skew slab whereas in case of single span deflection increases with increase in skew angle. This shows that the effect of deflection is more in single span skew deck slabs as the stiffness of slab is less.

2. Bending moment has reduced with increase in skew angle under dead load in single, two and three spans deck. But under moving load there is slight reduction in bending moment up to $20^{\circ}$ and then increased for $30^{\circ}$ and further reduced for $40^{\circ}$ skew angle only on single span deck.

3. When compared with all the three spans, the magnitude of bending moment has reduced its maximum value in single span deck. 
4. The magnitude of shear force has slightly reduced with increase in skew angle under dead load in two and three span deck, it was observed that the magnitude had increased under moving load.

5. In single span, the shear force remained same in all the models (skewed bridge) compared with normal bridge under dead load but there is increase in shear force with increase in skew angle under moving load.

\section{REFERENCES}

[1] Dattatreya et.al, "Effect of Skew Angle on Static Behavior of Reinforced Concrete Slab Bridge Decks", International Journal of Research in Engineering and Technology, Nov 2013, pp50-58.

[2] C. Menassa; M. Mabsout; K. Tarhini; and G. Frederick, "Influence of Skew Angle on Reinforced Concrete Slab Bridges", Journal of Bridge Engineering, Vol. 12, No. 2, March 1, 2007. CASCE, pp205-214.

[3] Ibrahim S. I. Harba, "Effect of Skew Angle on Behaviour of Simply Supported R. C. T-Beam Bridge Decks", ARPN Journal of Engg and Applied Sciences vol. 6, no. 8, august 2011, pp1-14.

[4] Amit Saxena et.al, "Comparative Study of the Analysis and Design of T-Beam Girder and Box Girder Superstructure", International Journal of Research in Engineering and Advanced Technology, April-May 2013.

[5] Ansuman kar et.al, "Study on Effect of Skew Angle in Skew Bridges", International Journal of Research in Engineering and Advanced Technology, Aug 2012, pp. 13-18

[6] N. Krishna Raju, (2010), "Design of Bridges", 4th edition

[7] IRC 6:2000 "Standard Specifications and Code of Practice for Road Bridges, Section-II Loads and Stresses", Indian Road Congress, New Delhi.

[8] IRC 21:2000 "Standard Specifications and Code of Practice for Road Bridges, Section-III Cement Concrete (Plain and Reinforced)", Indian Road Congress, New Delhi. 